\title{
The Medieval Subject and the Saga Hero
}

Abstract: In this article an attempt is made to understand the way medieval Icelandic sagas stage their characters as an expression of a conflict of norms within the society which produced them, i.e. Iceland in the thirteenth century. Two contemporary sagas show how this conflict of norms is part of the reality facing chieftains in a society where they must use violence to preserve their power and protect themselves and their kinsmen, but where the fate of their souls is also at stake in a Christian world-view forcefully promoted by a militant Church. Two sagas of Icelanders are then studied in which this conflict of norms is thematized as one between Christianity and paganism. The conflict of norms in question is instrumental in generating an image of the self which is generated by the forces in presence in medieval culture.

Keywords: subject, subjectivation, honor, revenge, governmentality, confession, social norms, libertas ecclesiae, privilegium fori

A question has haunted the study of Nordic medieval culture and Old NorseIcelandic literature from the beginning. It concerns the extent to which the sagas are about a tradition-bound society with roots in a pagan Viking culture and to what extent they are an expression of authors and audiences who belong to the Christian West of the High Middle Ages. There is not enough space here to describe the different forms this debate has taken through time (Andersson 1962; Mundal 1977; Clover 1984). One could say, however, that the opposing terms structuring it are on the one hand "ancient, autochthonous, and pagan," and on the other "recent, foreign, and Christian." The underlying idea is that thirteenth-century society and culture in Iceland and Norway were still under the influence of their pagan heritage, though they were being gradually transformed by the Church and an aristocratic culture originating in more southern parts of Europe.

In this article, an attempt will be made to reframe this question in light of recent research on the medieval self. By the early thirteenth century, when the oldest sagas studied in this chapter are believed to have been written, more than two centuries had elapsed since the conversion which took place around the year 1000. The Church was a well-organized and essential institution in the lives of Icelanders and Norwegians, who were neither less nor more Christian

Torfi H. Tulinius, University of Iceland

¿ Open Access. ( 2020 Torfi H. Tulinius, published by De Gruyter. (cc) BY-NC-ND This work is licensed under a Creative Commons Attribution-NonCommercial-NoDerivatives 4.0 International License. 
than their contemporaries in other parts of the medieval West (Orri Vésteinsson 1999). Instead of the above-mentioned terms, the argument made here will be that these sagas express a conflict of norms: between those governing the lives of lay people, more precisely laymen belonging to the dominant class, and those instituted by a Christian Church which had become more militant in this period because of the movement of Libertas ecclesiae. The secular norms aimed at increasing or preserving social status. The Christian norms involved the care of the soul in preparation for the afterlife.

Both sets of norms have to do with the self and its conduct within a social space, that of Nordic society in the thirteenth century. In this period, there was a significant tension between these two different sets of norms. This tension was particularly strong among the lay elite, the social group for whom the sagas seem to have been produced. It is related to a dynamic and ongoing process of change happening in medieval society at the time, not the least in Iceland. On the one hand, the royal state was being reinforced as an institution wielding power over society, on the other, the Church was attempting to reinforce its pastoral power over the laity. The sagas express this tension, as will be shown in the following pages.

A first section will present the historical developments leading to this tension between social norms and how it impacts the sense of self. Each of the four subsequent sections will focus on an individual saga text and describe how this conflict of norms is expressed within it. In conclusion, the article will discuss how this conflict of norms is constitutive of the medieval subject and is dramatized in the portrayal of the saga characters, especially those belonging to the Íslendingasögur genre or Sagas of Icelanders.

\section{Two Sets of Norms}

A social norm is a way of behaving and thinking defined and sanctioned by society and based on a system of reference that is both explicit and implicit. For sociologists, such as Elster, there are two types of social norms: formal norms, codified by a law or an official rule, or informal, i.e., an optional behavior which most members of a given society believe is necessary for it to function properly (Elster 2015). Norms are not necessarily codified or even expressed in words. In this respect, they are related to Pierre Bourdieu's concept of habitus which explains how socialization shapes perceptions, attitudes, and values, and therefore practice (Bourdieu and Wacquant 1992, 16-18; Torfi H. Tulinius 2014, 188-90). 
The first set of social norms relevant in Iceland around the year 1200 are those that govern a community that has neither king nor any form of organized police or military. The welfare of individuals is ensured by their ability to defend themselves against attacks. In order to do so, they must rely not only on their physical and military prowess, but also on a network of relatives, friends, and allies, obliged to support them in obtaining compensation for whatever damage they may have suffered or else in exacting revenge. On this could depend the security of the individual, but also his or her honor (Byock 2001, 77-80; Miller 1988, 179-89). The medieval sagas, especially the Sagas of Icelanders, are quite often structured by these social dynamics of revenge and counter-revenge. However, these dynamics can also be observed in sagas which take place in times much closer to the time of writing, and therefore describe events that their authors and audience may have participated in or witnessed (Helgi Porláksson 1994). This type of society therefore generates social norms, and the respect the individual enjoys in the eyes of others, as in his own, depends on his ability to conform to these norms. It is likely that these norms were at least already in place, at least in part, in the pagan society that preceded the conversion to Christianity.

Iceland converted to Christianity in the year 1000. Since then, particularly after the two episcopal seats at Skálholt and Hólar were founded, respectively, in the middle of the eleventh and the beginning of the twelfth century, and the Church was led by members of the local dominant class, i.e., the goðar or chieftains, a different set of social norms was progressively being integrated by the Icelanders. This was particularly true in the period beginning at the end of the eleventh century, with the beginnings of the libertas ecclesiae movement in the Christian West; this movement was initiated by Pope Gregory VII at the end of the eleventh century and aimed at freeing the Church from the authority of lay rulers and exercising greater control over society. Among the consequences of this important movement, we can mention the Peace of God, which were the efforts of the Church to curb violence within society by instituting days or periods of the year during which fighting was prohibited, enabling leaders of the Church to open procedures of excommunication in the case of transgressions. Closely tied to this was the call for Crusades in the Holy Land, this also being a part of an attempt by the clergy to "tame" chivalry. This trend can also be seen in literature in the vernacular, which was emerging in this same period, and appeared as the idea that chivalry is a sort of vocation, comparable to that of the clergy (Verderber 2013, 24-60).

In the same period, the Church engaged in many conflicts with kings and other lay leaders concerning its authority over its own matters. A good example is the Investiture Controversy, which pitted the pope against the emperor in a fight over the power to name members of the higher clergy, or the conflict over 
privilegium fori, i.e., the Church's claim to sole jurisdiction over legal matters concerning clerics (Southern 1970, 34-41).

While this was going on, the Church was taking the pastoral role of clerics as spiritual guides to laymen more seriously. New developments in religious thinking, such as Abelard's theology of intention, or the "birth of purgatory," described by Jacques Le Goff, increased the power of the Church over minds and souls (Le Goff, 1984). Indeed, the generalization of confession from the late-eleventh century onwards, made obligatory for every Christian at the 1215 Lateran Council, made demands on laymen that they examine their own inner life.

A recent book by Suzanne Verderber has demonstrated that all these developments are part of a greater change, i.e., the appearance of what Michel Foucault called "pastoral power." The Church had taken over the hearts and minds of each individual, forcing her or him to integrate new norms, which could be quite opposite to pre-existing ones and could therefore create conflicts within societies, and even within persons. Foucault called this process "subjectivation" and some have even said that the "modern subject," worrying about his sexuality and prone to self-examination, originated in this period (Verderber 2013). ${ }^{1}$

Christians in the thirteenth century were therefore in the process of integrating new norms, and Icelanders were no exception. Both the lay contemporary sagas and the bishop's sagas display numerous examples of warriors asking to confess their sins before dying, going to Rome to seek absolution, and giving property to the Church for the redemption of their own souls or those of family members. ${ }^{2}$ In Iceland, we also see conflicts between the higher clergy and lay chieftains showing that the former were pursuing the same aims, and the latter were opposing the same resistance to them as in other parts of Europe. ${ }^{3}$ Surviving

1 It is impossible to describe in detail this historical development summarized by Suzanne Verderber in her important book. Among the authors she cites are Jacques Le Goff, Michel Foucault, Walter Ullmann, Colin Morris, Peter Haidu, and several others.

2 People and events of the thirteenth century are chronicled in the compilation of contemporary sagas called Sturlunga saga (1988). Here are a few examples from the saga demonstrating the importance of Christianity in the lives of the lay dominant classes: Sturla Sighvatsson asked to confess to a priest in his dying moments (424). Earlier, he had gone on a pilgrimage to Rome to atone for an attack on members of the clergy (351). Some years later, his brother Pórðr gave a rich farm to the bishopric of Skálholt for the souls of their parents (548).

3 Sturlunga saga (1988, 214-27) describes the conflict between Bishop Guðmundur Arason and the lay chieftains about privilegium fori, among other matters. The biography of the bishop Porlákur tells of the conflict between the bishop and the most powerful chieftain of the country, Jón Loftsson, concerning authority over church property and attempts by the clergy to control the sexual behaviour of the laity (Biskupasögur II, 2002, 175-80). 
documents, such as synodal statutes and records of legal change, show that the Icelandic Church was conforming to the decrees of the universal Church. ${ }^{4}$

As in other parts of Europe, Icelandic society was engaged in a continuous and dynamic process. At the same time, the Icelandic chieftains were being progressively drawn into the orbit of the Norwegian royal state, which had been in crisis during most of the twelfth century but was becoming more stable and structured in the thirteenth (Ârmann Jakobsson 2014). At the same time, the Church was extending its power over laymen, imposing new norms that must interiorize, though this did not happen without resistance and strife.

In the following chapters, four sagas will be examined. Two contemporary sagas show how this conflict of norms was part of the reality facing chieftains in a society where they had to use violence to preserve their power and protect themselves and their kinsmen but where the fate of their souls was also at stake in a Christian worldview. An analysis of two Sagas of Icelanders will show how this conflict of norms is thematized as one between Christianity and paganism. The conflict of norms in question was instrumental in generating an image of the self that was the product of the forces present in medieval culture.

\section{Differing Status of Characters in Different Saga Genres}

As a preliminary to the study of the four sagas, it is important to note that the status of characters from contemporary sagas is different from that of characters represented in the Sagas of Icelanders, or Íslendingasögur. The characters from the contemporary sagas lived in the same times as the members of the audience for whom the sagas were composed. The characters and events depicted were therefore known to this audience. This limited the freedom of the authors to allow their imagination to transform them. These limitations were far less for those who composed the Íslendingasögur. Unlike the contemporary sagas, the Sagas of Icelanders stage characters who belonged to the generations which settled in Iceland and their immediate descendants until shortly after the conversion of the country to Christianity around the year 1000, i.e., people living more than two centuries before they became the object of these narratives. It is

4 See, for example, synodal statutes that Bishop Magnús Gizurarson had approved at the parliament (Alpingi) in 1224. He is clearly applying some of the decisions taken at the Lateran Council in 1215 (Diplomatarium Islandicum. Íslenzkt fornbréfasafn, I, 436-37). 
likely that these stories were based on authentic memories of events and people from this early period that had been transmitted orally throughout the generations. However, as shown by memory studies, collective memory reconstructs and transforms recollections, adapting them to the needs of the present. ${ }^{5}$ It is also likely that the authors of these sagas gave themselves a certain amount of artistic license to construct their characters according to the meaning they intended to give to their stories.

The characteristics of the times in which these sagas take place gave even more freedom to the authors. It was the time in which their society, the institutions which governed it, and the power relations that structured it originated, at least to a certain extent. But it was also a period when Icelanders were still pagans, or in a process of transition from heathendom to Christianity. The result was that the fictional world of the characters of the Íslendingasögur allowed the expression of a certain ambiguity. This ambiguity was religious, but also moral, social, and psychological (Torfi H. Tulinius 2000). This ambiguity must have resonated with thirteenth-century Icelanders, caught in conflicts which called for violence to be exercised or revenge to be accomplished, but which went against the precepts of the Church, which also had a strong hold on their hearts and minds.

\section{Hrafn Sveinbjarnarson's Pastoral Power}

The saga of the Icelandic chieftain Hrafn Sveinbjarnarson (d. 1213), Hrafns saga Sveinbjarnarsonar, is likely to have been composed in the 1240 s. $^{6}$ It is the only one of the contemporary sagas devoted to the life of a lay chieftain that has been preserved as an independent work. There were other such biographical works, but they have only survived as parts of the fourteenth-century compilation known as Sturlunga saga. Hrafns saga has many remarkable aspects. Like other contemporary sagas, it narrates a struggle between lay chieftains, in this case between the main character, Hrafn, and the other major chieftain of the Westfjords

\footnotetext{
5 Maurice Halbwachs (1950) is widely considered to have founded memory studies. A recent and thorough overview of memory studies in pre-modern Scandinavia is provided by Glauser, Hermann, and Mitchell (2018).

6 In the foreword to her edition of the saga, Guðrún P. Helgadóttir presents the complex manuscript transmission of the saga, with information about the individual manuscripts. They are all considerably younger than the period of composition, for which she presents convincing arguments (Hrafns saga Sveinbjarnarsonar 1987, lxxxviii-xci and cviii-cxvi).
} 
peninsula, Porvaldr Snorrason. The conflict ends with Hrafn's killing by Porvaldr's men during Lent in the year 1213 (Hrafns saga Sveinbjarnarsonar 1987, 43).

The saga contains many biographical details concerning Hrafn, especially about his service as chieftain to the community. He provided hospitality to all and food to those in need. He maintained ships that ferried people over the fjord where he lived, Arnarfjörðr, and even over the much larger neighboring fjord, Breiðafjörðr. Most remarkable of all was the medical care he gave to the ailing. It is the description of Hrafn's healing that has received the most attention from scholars, who have shown that he was well abreast of developments in medical knowledge in contemporary Christian Europe (Hrafns saga Sveinbjarnarsonar 1987, xci-cviii).

Furthermore, and this is relevant to the argument developed in this article, it is noteworthy that the anonymous author of the saga uses vocabulary to describe Hrafn's chieftainship which is different from other saga authors. The word used to designate his authority over people of his region is a hapax legomenon: "mannavarðveizla," which means to preserve people, to defend, and even to care for them (Hrafns saga Sveinbjarnarsonar 1987, 4). The other sagas use "mannaforráð," which denotes authority without the dimension of preservation or care. It is tempting to relate the choice of this term to a stronger religious dimension of this saga compared to what we know of other sagas about lay chieftains of the period (Hrafns saga Sveinbjarnarsonr 1987, xxv; Ásdís Egilsdóttir 2016). Indeed, Hrafns saga begins with a statement explaining the Christian doctrine of free will, which is unique in a saga about a layman.

Hrafn's conduct is exemplary, not least his death; in many ways, it is reminiscent of that of the martyr of the faith St. Thomas Becket, the archbishop of Canterbury who was killed by the men of Henry II Plantagenet, in one of the conflicts between members of the high clergy and lay aristocrats characteristic of the period. Other aspects of his behavior, such as reluctance to exercise violence, or the way he comports himself before his execution, remind one of St. Magnus of Orkney, a well-known character from saga literature who was revered as a saint in the whole North Atlantic region (Ásdís Egilsdóttir 2016, 82).

Though implicit, this comparison places Hrafn in the context of the conflicts between Church and lay chieftains which were prominent in this period of Icelandic history. Hrafn was one of the very few members of the chieftain class who stood by the bishop Guðmundr Arason in his conflict with most of the other chieftains of the country. In contrast, Hrafn's rival for power over their home area, the Westfjords, participated enthusiastically in an attack against the bishop's seat in 1209 (Hrafns saga Sveinbjarnarsonar 1987, 29). The bishop and Hrafn had been friends for a long time. Hrafn had organized and lead Guðmundr's trip to Norway where he was consecrated. In addition, Hrafn could boast of his 
friendship with bishop Bjarni Kolbeinsson of Orkney. He visited the islands at least twice during his lifetime (Hrafns saga Sveinbjarnarsonar 1987, 2).

The choice of the word "mannavarðveizla" for the type of authority that Hrafn had over his men might be interpreted as an indication that the Church in the Nordic countries of the time was promoting a model of lay chieftain which was based on an ideal of service which was common to all of the clergy of medieval Christianity. This ideal has been studied recently by the historian Jacques Dalarun in his book Gouverner, c'est servir (Dalarun 2012). Closely connected to the Church's, at the time rather recent, efforts to have more control over laymen, it was legitimized by, among other passages from Scripture, that of the parable of the prodigal son (Luke 15:3-7). Jesus explains that, like the good shepherd who is more worried about the lost sheep than those that remain in his flock, so God rejoices more over one sinner who repents than 99 others who have not sinned. Like the good shepherd, those who do God's work must care both for the community as a whole and for each sinner as an individual. Michel Foucault maintains that this idea is among a set of concepts and representations which have accumulated over centuries in our culture. Together, they form what Foucault calls western "governmentality," a "dispositive" or system of power with diverse consequences, one of them being the subjectivizing processes which created the western individual. ${ }^{7}$

Hrafn was not only a chieftain, but also a "good shepherd." Narrating Hrafn's life within this framework sheds light on the way the saga author qualifies two other characters: Hrafn's cousin, Ragnheiðr Aronsdóttir, who is a rich and influential widow in her community, and Pórðr Snorrason, a good chieftain who died too young, leaving the power of his area to his younger brother, Porvaldr, who would become Hrafn's rival and eventually have him killed. The same expression is used to describe these individuals: "hvers manns gagn," i.e., of use or in service to each and all (Hrafns saga Sveinbjarnarsonar 1987, 17). This confirms the existence in thirteenth-century Iceland of social norms which propose a model of behavior which was different from that shown by other representatives of the dominant classes of society. ${ }^{8}$

7 See Philippe Büttgen (2007) for an overview of this aspect of Foucault's thought with many useful references to Foucault's writings. Paola Rebughini (2014) discusses in detail the concepts of subject, subjectivity, and subjectivation.

8 In Torfi H. Tulinius (2016), I present my analysis of Hrafns saga in more detail than space allows for in this volume. 


\section{Resisting Pastoral Power: Gizurr Avenges His Family}

One of the most memorable sections of Sturlunga saga describes the attack and burning down of the large farm of Flugumýrr in northern Iceland in 1253. It was the residence of Gizurr Porvaldsson, one of the main chieftains of the country and a member of the Norwegian king's court, who had given him authority over this region of Iceland. He was also the descendant of many historical bishops of the country, as well as the great-great-grandson of a Norwegian king. Well-born and a talented leader of men, he had participated in many of the conflicts of this troubled period in Icelandic history. Fifteen years earlier, in 1238, he killed with his own hands the leader of the Sturlung family, Sturla Sighvatsson, in the aftermath of a battle in which Gizurr and his allies had won a decisive victory over Sturla's army. In the years that had since elapsed, the Norwegian king had increased his influence over the Icelandic dominant class, even though one more decade would pass until the Icelandic chieftains and the principal landowners swore allegiance to him (Sverrir Jakobsson 2016). In 1253, Gizurr returned to Iceland after dwelling at the Norwegian court and completing a pilgrimage to Rome to atone for sins he had committed, but about which the sources do not otherwise inform us. He now busied himself making peace with his former enemies (Sturlunga saga 1988, 568). In order to consolidate these new alliances, he arranged a marriage between one of his three sons, Hallr, and Ingibjörg, the daughter of Sturla Pórðarson, who by then had become one the most prominent chieftains of the Sturlung family. This Sturla is also the presumed author of the narrative which tells us of the dramatic events which followed (Sturlunga saga 1988, 628-50).

Some of the late Sturla Sighvatsson's closest followers did not wish to reconcile with Gizurr. This is especially true of one of his surviving daughters, who was married to Eyjólfr Porsteinsson, an impressive warrior who had most notably distinguished himself in the warfare that took place in the 1240s when Sturla's brother, Pórðr kakali, lead the attack on Gizurr and his allies, and which had resulted in a temporary improvement of the position of the Sturlung family. After having been taunted in a particularly humiliating way for his unmanliness by his wife and mother-in-law, he sets out with a group of men to attack Gizurr's estate, two nights after the wedding of Gizurr's son Hallr to Ingibjörg. Most of the guests had departed and therefore only the men of Gizurr's immediate household were there to defend him, his wife, three sons, and his new daughter-in-law. They managed, however, to hold their assailants at bay until the assailants decided to burn Gizurr's hall down. The men who 
escaped from the burning house were killed and the women spared. Those who stayed inside died in the flames. Gizurr was the only survivor of his family, having managed to escape against all odds. The morning after, when he returned to his manor in ruins, he found his wife and three sons all dead.

His daughter-in-law, Ingibjörg Sturludóttir, had narrowly escaped, as one of the attackers, a close cousin of the young woman, had run into the burning house to save her. The father of the young woman, who had been present at the wedding and had just recently left the region, and who tells the story, seems to take a particular interest in the resilience shown by Gizurr in these tragic circumstances. Before the charred remains of his wife and one of his sons, he says their names, as if to give them back their humanity. Despite his sorrow, he kept his composure and managed to sleep. Some weeks later, he composed a skaldic stanza in which he said that he would never know happiness again unless his wife and three sons were avenged:

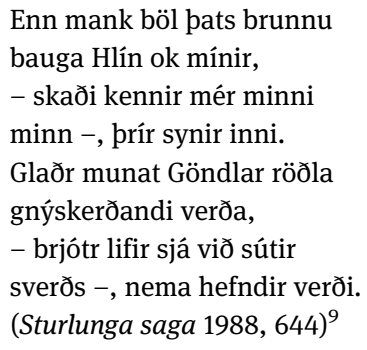

However, the local higher clergy had imposed a truce upon the warring factions. Gizurr's enemies, most of whom lived in the neighboring fjord, seemed to feel that they were safe. That was when Gizurr launched an attack, killing several of his assailants, especially an important member of the Sturlung family. He now felt that he had accomplished adequate revenge and composed another stanza saying that he could now bid farewell to his grief:

Borg lét brennuvarga
bjórstofnandi klofna
Sónar sex ok einum
(sák deili pess) heila;
bergstjóra gleðr báru
blikstríðanda síðan
hregg, en hafnak muggu

9 I can still remember the evil when my wife and three sons were burned inside. My loss teaches me to remember. The warrior (the breaker of swords) who lives in sorrow will not be glad unless revenge takes place. (My translation). 
heldr, síst Kolbein feldum.

${\text { (Sturlunga saga } 1988,649)^{10}}^{10}$

The bishop, however, was furious that Gizurr had broken the truce and excommunicated him and his men. This was of course a serious punishment for a medieval Christian, because without absolution from the Church, they would all be consigned to the eternal flames of Hell. Gizurr's decision to seek revenge was therefore a grave one, involving a huge risk. One must ask oneself why he did not await King Hákon's judgement, as the terms of the truce called for, and which his assailants had requested (Sturlunga saga 1988, 644).

It is also possible to reverse the question and ask what it would have meant for Gizurr not to avenge himself. It is rather likely, given the many killings that had already taken place in the previous decade and a half, that the king's arbitration would have taken into account the numerous deaths inflicted on the Sturlungar by Gizurr. His craving for revenge - extremely strong given the circumstances - would not have been alleviated (Jaffe 2011). More importantly, by accepting not to avenge his family, Gizurr would have been going against the norms of the society in which he grew up and became who he was. He would have lost the respect of his men, many of whom had also been injured or lost friends and kinsmen in the attack. Moreover, he could have thought that his enemies would not fear him as much anymore, if he did not retaliate. Finally, his own self-esteem would have been severely impaired, not only by repressing his natural inclination to avenge such a traumatic blow, but also by not behaving in accordance with social norms to which he adhered profoundly.

To do so, he was obliged to go against another set of social norms which were imposed by the Church, but to which Gizurr must also have adhered. It is in this context that his use of poetry may be understood. As shown by Jonathan Grove, skaldic stanzas which circulated between residences of chieftains and other prominent thirteenth-century Icelanders were part of what we would call "political communication" in modern terms. The authors of these stanzas are commenting on recent events, sometimes taking sides in the underlying conflicts (Grove 2008). Therefore, Gizurr's two stanzas should not be understood only as expressions of personal grief, but as public acts of communication in which he is making his pain apparent in order to garner sympathy and support for his actions beforehand and afterwards.

10 The poet (the founder of the beer of Són) had the skulls of the burners (fort of brains) cleft open. I saw it. Poetry (snow of the governor of mountains) cheers up the warrior (the breaker of gold), since Kolbeinn was slain. I refuse sadness (snowfall). (My translation). 
Our sources do not tell us whether Gizurr managed to reconcile with the Church. It is probable, otherwise the king would not have given him the title of “jarl” just a few years later (Sturlunga saga 1988, 780). What is interesting in the context of this article is the choice between two sets of social norms made by Gizurr. For political reasons, he was forced to choose those that dominated lay society. This does not, however, mean that he could free himself of the constraints of the processes of subjectivation that had already been active for several generations in the middle of the thirteenth century. Quite the contrary, he expressed the "interiority" that religion had taught him he had, or in more foucauldian terms, his subjectivity. Indeed, his stanzas highlight his pain but also the almost therapeutic effect revenge had on him. His pain made him unable to forget the death of his wife and sons. To relieve it, revenge was necessary, and once it was obtained, he was rid of his sorrow.

The hypothesis that this way of thinking is more under the influence of recent development in society and culture, rather than being consubstantial to a culture of honor and revenge, is supported by the fact that Gizurr borrows from Cicero a crucial line in one of his stanzas. Indeed, the line "skaði kennir mér minni minn" (my loss teaches me to remember) is quite likely a reference to a ciceronian aphorism, "qui doluit, meminit" (he who suffers, remembers), which was well known in clerical circles in this period (Hermann Pálsson 1983). ${ }^{11}$

The two characters from contemporary sagas, Hrafn and Gizurr, chose to behave in accordance with opposite sets of social norms. Gizurr avenged his loss on his attackers, while Hrafn displayed clemency towards his attacker, Porvaldr Snorrason, on several occasions. Porvaldr did not, however, change his behavior, and in the end killed Hrafn.

It is likely that the almost hagiographic portrait the author of Hrafns saga gave of his protagonist, a few decades after his death, does not correspond entirely to reality. Hrafn may not have followed the precepts of the Church as scrupulously as he is shown to have done in the saga. It is quite likely that he also behaved often in accordance with the norms of the lay chieftain. However, the saga mentions several occasions when Hrafn's men criticize him for not killing Porvaldr when he had the opportunity (Hrafns saga Sveinbjarnarsonar 1987, 32 and 36). In addition, other sources inform us that, once they had grown up, Hrafn's sons avenged their father by killing Porvaldr (Sturlunga saga 1988, 307-9). Just like Gizurr, Hrafn must have often felt the opposing pressures of the two sets of norms.

11 A more detailed analysis of this episode is to be found in Torfi H. Tulinius (2017). 


\section{Egill Skalla-Grímsson: Resisting Royal Power and Negotiating with Pastoral Power}

Egils saga Skalla-Grimssonar may well be the earliest major representative of the Íslendingasögur genre or Sagas of Icelanders (Jónas Kristjánsson 1990). ${ }^{12}$ It was probably composed in the period between 1230 and 1240. It is a long, ambitious, and complex work. The events depicted span more than a century, though most of the focus is on its enigmatic main character, the poet and warrior, Egill SkallaGrímsson.

It is impossible to give a satisfactory account of this great saga in the limits of a short article. ${ }^{13}$ It begins by telling the story of a first generation of prominent Norwegians. One of the sons of the family decides to enter the service of King Harald Finehair. To begin with, he gains both glory and wealth, but soon the jealousy of courtiers and the suspicious nature of the king result in him being deprived of his position. Lacking resources to maintain his standard of living, he resorts to attacking a cargo ship belonging to the king, who in retaliation attacks his farm and kills him. His father and brother, Skalla-Grimr, avenge him by killing the king's cousins. They must leave Norway and decide to move to Iceland, which had recently been discovered. Skalla-Grimr takes for himself a large area of unsettled territory, that of the Borgarfjöror region, dividing the land between his kinsmen and followers.

When the saga was composed, this district was dominated by his distant descendant Snorri Sturluson (1179-1241). Snorri was not only the author of king's sagas for which he is best known, but also a poet and a major chieftain in his time, as well as a high-ranking dignitary of the Norwegian court. ${ }^{14}$ It is likely that Snorri himself composed Egils saga, though it is a difficult thing to prove as no medieval source attributes the saga to him. It is, however, quite certain that whoever composed it was quite close to Snorri in time and space, and that the time of writing was near the end of Snorri's life (Torfi H. Tulinius 2014, 211-7). A recent comparative study of the vocabulary of works attributed to Snorri provides additional arguments in favor of his authorship of the saga (Haukur Porgeirsson

12 The manuscript transmission of Egils saga is summarized in Egils saga Skallagrimssonar (2001, xix-xxi). There are three main medieval text witnesses (A, B, and C). AM 132.fol is the best representative of the A-text. Wolfenbüttel, Herzog August Bibliothek 9. 10. Aug. 4to contains the B-text, whereas AM 462 4to and 453 4to are seventeenth-century copies of a now lost medieval manuscript.

13 All references to the text of the saga will be to Bjarni Einarsson's 2003 edition.

14 Sturlunga saga is the main source about Snorri's life. A recent discussion of his life and works is to be found in Guðrún Sveinbjarnardóttir \& Helgi Porláksson (2018). 
2018). The oldest fragment of a manuscript of the saga is dated to the middle of the thirteenth century and is believed to be a copy of the original (Egils saga Skallagrimssonar 2001, lix). Snorri was killed in 1241. In a book published in 2014, the present author proposes a detailed reading of the saga, not only of its elaborate structure but also of how meaning is suggested by intertextual allusions, not least to stories and themes from the Bible (Torfi $\mathrm{H}$. Tulinius 2014).

The main character of the saga, Egill, is the son of the first settler, Skalla-Grimr. Egill's older brother dies and Egill inherits his father's authority over the region. He is also a fierce warrior but - most importantly - an exceptionally talented practitioner of skaldic poetry. Three long poems by Egill are to be found in manuscripts of the saga, as well as a great number of individual stanzas. This would suffice to inspire Snorri and his milieu to celebrate the memory of Egill. Indeed, Snorri had united several individual chieftaincies and ruled over the area settled by Egill's father, in association with close cousins, all of which belonged to a long line of chieftains and poets descended from Skalla-Grimr. In addition, no one cultivated the art of skaldic poetry more than Snorri and his entourage. Though best known for the mythological information it gives, Snorri's Edda is above all a treatise on skaldic poetics (Guðrún Nordal \& Jon Gunnar Jørgensen 2018, 454-8).

Nevertheless, the few sources mentioning Egill, other than the saga, all seem to be dependent on it. That is why it is very likely that the story of Egill and his family reflects the outlook and concerns of the Sturlung clan around 1240, a period in which its members are in a deep crisis. As was said earlier, their chieftain Sturla Sighvatsson had been defeated and killed in battle in 1238, alongside Sturla's father, Sighvatr, who was Snorri's older brother, as well as several of Sighvatr's other sons. In the decade and a half preceding this battle, the solidarity of the clan had been severely tested by the conflicting ambitions of Snorri and his nephew Sturla, both of whom had strong links to the Norwegian court and were in a position to rule Iceland in the king's name. Indeed, tensions had run so high between these close relatives that violence had erupted on several occasions, culminating in Sturla's invasion of Snorri's domain on Palm Sunday 1236, forcing his uncle to flee. After a battle between Sturla's and Snorri's followers, among them his close maternal cousins who ruled over the southern part of the Borgarfjörðr distict, Snorri resolved to sail to Norway where he stayed at the court of Duke Skúli, father-in-law of the king and former regent of the throne, but who was now competing with his son-inlaw, King Hákon, for power over the country. ${ }^{15}$

15 The conflict between King Hákon and his father-in-law, Duke Skúli, is described in detail in a work composed by another of Snorri’s nephews, Sturla Pórðarson, Hákonar saga Hákonarsonar. 
When news arrived in Norway about Sturla's defeat in 1238, Snorri hastened back to Iceland, even though King Hákon had ordered him to stay. During the remaining few years of his life, he seems to have made every possible attempt to reconcile the surviving members of the Sturlung family, while he was simultaneously re-establishing his authority over the western part of Iceland. This involved, among other things, arranging a marriage between one of the two surviving sons of his brother, Tumi Sighvatsson, to his own sister-in-law, Puríðr Ormsdóttir, a member of the prestigious Oddaverjar family. The wedding was celebrated in Reykholt, Snorri's residence (Sturlunga saga 1988, 433). Sources tell us that wedding feasts among the upper echelons could take many days, even a whole week (Ârni Björnsson 1996, 230). In the book on Egils saga, mentioned above, it is suggested that the saga may have been composed to be read aloud to entertain the guests at the wedding (Torfi H. Tulinius 2014, 262-6). It is known that saga material was used to entertain guests at social gatherings in this period (Torfi H. Tulinius 2018, 393-4). They could be told or read aloud. Egils saga is long enough to read in hour-long instalments for the five to seven evenings of the wedding feast. As has already been noted, it narrates the time period that defines the social identity of the social group present at the wedding. In addition, in the main part of the saga, the one devoted to the life of the main protagonist, Egill, subtle allusions are made to the fratricidal conflicts that had torn the clan apart for more than a decade (Torfi H. Tulinius 2014, 223-55).

Indeed, if Egill is a pagan, the saga also suggests that he is a sinner in the Christian sense. This is done by developing a complicated plot, interlacing the account of two conflicts. The more visible one is that between Egill and the Norwegian king Eiríkr blóðöx, but another more hidden one opposes him to his older brother and father. An indirect result of this conflict is the death of the brother during a battle fought in England. This allows Egill to marry his brother's widow and inherit his position and wealth. Egill's responsibility is indicated using intertextual allusions to the Bible, most prominently to the story of King David, which had multiple meanings for medieval Christians. David was one of the Righteous of the Old Testament, which meant that his soul would be saved on Judgement Day; he was a great founding poet, as well as a sinner, because he had conspired to have the husband of the woman he lusted after killed in battle. David was punished for this sin by the death of his first-born. He also composed the seven penitential psalms, which were recited by medieval sinners after confession and atonement (Vincent 2000).

The slaying of Skúli by Hákon's men is described on pp. 113-15. See also Hans Jacob Orning (2018) for a recent analysis of their conflict. 
As is demonstrated in the book about the saga, the author of Egill's life weaves into it subtle allusions to the story of David (Torfi H. Tulinius 2014, 97-110). The intended readers or audience of the sagas, at least many of them, cultivated skaldic poetry, an art of intertextuality if ever there was. Many of them also belonged to the clergy or had received some degree of clerical training. They would have understood the subtleties of biblical exegesis. They were therefore capable of perceiving the underlying allusions to David and understand them in the context of the history of salvation. Like David, Egill had a chance of being admitted to Paradise, even though he lived his whole life before the conversion, the equivalent in Icelandic history to the Incarnation in the history of humanity. His chances of going to Heaven were even greater, as he had received the prima signatio, a sort of shorter baptism (Harris \& Hill 1989, 116; Torfi H. Tulinius 2014, 66-67). The narrative at the end of the saga of three places where his bodily remains are laid to rest signify his intermediary status in terms of medieval Christian thinking. He is first buried in a pagan gravemound, then moved, when Iceland converts to Christianity, to a recently built church. A century and a half later, the church is being moved and Egill's bones are discovered under the altar. That is not an appropriate place for someone who had only been prime-signed, and his bones are moved once again to the outskirts of the cemetery, which is the prescribed resting place for the bones of those having only received the shorter baptism in the Icelandic law of the thirteenth century (Torfi H. Tulinius 2014, 2-7).

Egill is therefore ambiguous, and it is this ambiguity which is of interest to the present article. On the surface, he seems to adhere exclusively to the norms of the ruling society before the Church began to transform hearts and minds: honor, revenge, fidelity to one's kin. However, the author suggests that Egill's story must also be understood in the context of the norms promoted by the Church. This ambiguity must have appealed to Snorri's entourage, and more generally to the social group it belonged to. Like Snorri himself, who may well have conspired to have his nephew killed, many members of his social group had found themselves in an ambiguous position in relation to these two sets of norms which governed their lives (Sturlunga saga 1988, 316-8).

\section{Conflict of Norms and Tragedy: Gunnarr and Flosi}

Egill is a literary character, even though he is based on the memory of a real person who lived two to three centuries before the saga was composed. However, he is not a tragic hero. His life was full of dramatic events, but he lived to an 
advanced old age and died peacefully. The world of the sagas is nevertheless full of what could be called tragic characters. The most remarkable of these is without doubt Gunnarr Hámundarson, one of the main characters of BrennuNjáls saga. Gunnarr and another figure of the saga will be the topic of this concluding section.

Gunnarr died at the hands of his enemies after a heroic battle which he had fought alone against 80 men who had surrounded his farm. The country was still pagan, and Gunnarr is buried in a grave-mound close by. As mentioned above, Egill had received a sort of shorter baptism and was at least partly Christian, as is indicated by his final resting place on the outskirts of a Christian cemetery. Gunnarr's burial in a mound confirms that he lived all his life as a pagan. Shortly after his death, he is seen inside his mound, bathed in a supernatural light. He is gaily chanting a skaldic stanza where he declares his happiness at having fought his enemies (Brennu-Njáls saga 1954, 191-4).

This paranormal scene could be interpreted as a commentary made by the author. Gunnarr represents the norms of a society that is ruled by a code of honor which demands that the individual and those to whom he is bound by familial or other ties take up arms against their mutual enemies. That is how the apparition is understood by Gunnarr's friend Skarphéðinn, who offers his help to Gunnarr's son in his quest for revenge. However, Gunnarr is a much more complex character than that, for he has on many occasions shown remarkable restraint and been willing to forgive those who had offended him. On one occasion, he even abstained from asking for compensation for the killing of a close member of his family, so as not to jeopardize his friendship with Njáll and his sons. His cousin had gravely offended his friends by composing and reciting scurrilous verse at their expense (Brennu-Njáls saga 1954, 118).

Gunnarr is in this sense full of contradictions. Despite his exceptional prowess as a fighter, he is also introspective, confessing to his brother at one point that he sometimes asks himself if he is less of a man than others because it pains him to kill people (Brennu-Njáls saga 1954, 138-9). It is as if the author had wanted to represent what the Swedish scholar Lars Lönnroth has called the "noble heathen," i.e., someone to whom the true religion has not been revealed but feels the murmurings of a Christian conscience (Lönnroth 1969). Using the concepts that have been proposed in this article, he follows the norms of a society based on revenge but feels obscurely the pressure of the norms advocated by the Church.

Like many representatives of this saga genre, Njáls saga includes a narrative of the conversion of Iceland to Christianity, to which it devotes several chapters (Brennu-Njáls saga 1954, 255-72). The change of religion does not, however, lead to a decrease in violence. Instead, the most serious acts of violence in the saga take place afterwards. This is particularly true of the burning down of Njall's 
farm, resulting in his death and that of his wife and three sons. Njáls saga is much too complex a work for it to be analyzed here. For the needs of the argument proposed in this article, one more example will be taken, that of Flosi, the chieftain who ordered the attack and burning down of the farm.

Flosi is not introduced into the saga until the second half. To begin with, his role is secondary. However, his role increases progressively, and as the saga ends, he has become one of the two main protagonists. Its final episode tells how he disappears at sea, on his way back from Norway as an old man (Brennu-Njáls saga 1954,463$){ }^{16}$

As the plot develops, Flosi is confronted with a terrible choice. He is the most powerful chieftain of his kin-group. Njáll's sons having killed the husband of his niece, and social norms dictate that he must either demand compensation or exact revenge. A wise man, capable of restraint, he prefers the former option. His niece, however, wants blood to be shed for the killing of her husband and does not even refrain from invoking Flosi's masculinity in an attempt to force him into action (Brennu-Njáls saga 1954, 291). He resists for a while, but during a scene where his manliness is again being insulted, he cannot restrain himself, which results in a settlement being impossible between the two factions (BrennuNjáls saga 1954, 313-4). He has no choice but to attack Njáll's farm, but his sons and their men defend it valiantly. They cannot be vanquished and soon they will be receiving help from neighbors. The only way Flosi can overcome his enemies is to burn down the farm with his enemies inside. If he does not, he knows that he and his men will be made to pay dearly for the failed attack. The saga presents the alternatives facing Flosi as one between burning down their enemies' farm or facing certain death for themselves. Flosi adds: "It is a great responsibility before God, as we are ourselves Christian” (Brennu-Njáls saga 1954, 328).

The chain of events has forced this tragic choice on Flosi. Unlike Gunnarr, who is still a pagan, he knows what his religion calls for him to do. He understands he is about to commit a terrible sin. He also understands that his social role as leader of men, and responsible for their safety, demands that he commit it. The parallel is striking between Flosi, who is a fictional character, though a person with this name probably existed, and the historical figure Gizurr Porvaldsson, who was discussed above. ${ }^{17}$ He also had to choose between two sets of norms, the ones a lay leader of men must follow, and those

16 On the motif of accepted death in the saga, see my article "Seeking Death in Njáls saga" (Torfi H. Tulinius 2015).

17 The numerous parallels between the dramatic events of the middle of the thirteenth century and those described in Njáls saga have often been commented on. The most detailed study conducted on these parallels remains Barði Guðmundsson’s (1958). 
to whom a Christian subject must submit. The difference between Gizurr, who was a person of flesh and blood known to the author of the saga, and Flosi, who is a more or less imaginary character from a relatively distant past, is that the author Njáls saga is able to suggest more about the inner life of his characters through his choice of what he tells us.

\section{Concluding Remarks}

These four examples from two types of sagas show that the old debate between autochthonous elements and foreign influences, or paganism and Christianity, can be formulated in different terms with good results. The stories composed by the saga authors, both about the present and the past, were shaped by the conflict between the norms they felt under pressure to obey. The contemporary sagas are a unique source for those interested in the development of the medieval subject, in the way they present real-life characters in their attempts to negotiate between the demands of the social world to which they belonged and the equally demanding representations of the afterlife where their behavior in their lifetimes would be judged on the basis of the values promoted by the Church. The members of the dominant class of Icelanders in the thirteenth century were therefore beset by the contradictions inherent in this conflict of norms. The friction inherent in this situation is constitutive of the medieval subject or self.

The Sagas of Icelanders, or Íslendingasögur, telling of events taking place in the period in which their society was being founded, gave the thirteenthcentury authors the opportunity to communicate with their audience about this conflict of norms which many of their contemporaries must have experienced. The image of the past drawn up by these authors created a fictional space in which the ambivalent feelings Icelanders had for these norms were explored. The heroes of the Sagas of Icelanders are products or expressions of the ambivalent attitude medieval Icelanders had towards their own self within the social space with all its conflicting demands. Their narratives about the period in which their social world originated provided them with a novelistic mental space in which they could explore these contradictions without experiencing the discomfort of looking at themselves. In the words of the great modern novelist Milan Kundera, the saga authors had created "a territory where moral judgements were suspended” (Kundera 1993, 17). 


\section{References}

\section{Primary Sources}

Biskupasögur II. 2002. Ed. Ásdís Egilsdóttir. ÍF 16. Reykjavík.

Brennu-Njáls saga. 1954. Ed. Einar Ól. Sveinsson. í 12. Reykjavík.

Diplomatarium Islandicum. Íslenzkt fornbréfasafn. 1857. Ed. Jón Sigurðsson. Copenhagen.

Egils saga Skallagrímssonar. Bind I A-redaktionen. 2001. Ed. Bjarni Einarsson. Editiones

Arnamagnæanæ. Series A, vol. 19. Copenhagen.

Egils saga. 2003. Ed. Bjarni Einarsson. London.

Hákonar saga Hákonarsonar. 2013. Eds. Sverrir Jakobsson and Pórður Ingi Guðjónsson.

íF 32-33. Reykjavík.

Hrafns saga Sveinbjarnarsonar. 1987. Ed. Guðrún P. Helgadóttir. Oxford.

Sturlunga saga I-II. 1988. Ed. Örnólfur Thorsson et al. Reykjavík.

\section{Secondary Sources}

Andersson, Theodore M. 1964. The Problem of Icelandic Saga Origins: A Historical Survey.

Yale Germanic Studies, 1. New Haven and London.

Ármann Jakobsson. 2014. A Sense of Belonging: Morkinskinna and Icelandic Identity c. 1220.

Viking Collection, 22. Odense.

Árni Björnsson. 1996. Merkisdagar á mannsævinni. Reykjavík.

Ásdís Egilsdóttir. 2016. "Hrafn Sveinbjarnarson, Pilgrim and Martyr.” In Fræðinæmi. Greinar

gefnar út í tilefni 70 ára afmælis Ásdísar Egilsdóttur. Reykjavík. 79-89.

Barði Guðmundsson. 1958. Höfundur Njálu. Safn ritgerða. Reykjavík.

Bourdieu, Pierre and Loïc J. D. Wacquant. 1992. An Invitation to Reflexive Sociology. Cambridge.

Büttgen, Philippe. 2007. “Théologie politique et pouvoir pastoral.” Annales: Histoire, Sciences Sociales, 62.5: 1130-33.

Byock, Jesse L. 2001. Viking Age Iceland. London.

Clover, Carol J. and John Lindow, eds. 2005. Old Norse-Icelandic Literature: A Critical Guide. Medieval Academy Reprints for Teaching, 42. Toronto.

Dalarun, Jacques. 2012. Gouverner, c'est servir. Essai de démocratie médiévale. Paris.

Elster, Jon. 2015. "Social Norms." In Explaining Social Behavior: More Nuts and Bolts for the Social Sciences. Cambridge. 347-64.

Glauser, Jürg, Pernille Hermann, and Stephen A. Mitchell, eds. 2018. Handbook of Pre-Modern Nordic Memory Studies. Interdisciplinary Approaches. De Gruyter Reference. Berlin.

Grove, Jonathan. 2008. "Skaldic Verse-Making in Thirteenth-Century Iceland: The Case of the Sauðafellsferðarvísur." Viking and Medieval Scandinavia 4: 85-131.

Guðrún Nordal and Jon Gunnar Jørgensen. 2018. "The Literary Legacy of Snorri Sturluson.” In Snorri Sturluson and Reykholt: The Author and Magnate, His Life, Works and Environment at Reykholt in Iceland. Ed. Guðrún Sveinbjarnardóttir and Helgi Porláksson. Copenhagen. 441-68. 
Guðrún Sveinbjarnardóttir and Helgi Porláksson, eds. 2018. Snorri Sturluson and Reykholt: The Author and Magnate, His Life, Works and Environment at Reykholt in Iceland. Copenhagen.

Halbwachs, Maurice. 1950. La mémoire collective. Bibliothèque de sociologie contemporaine. Paris.

Harris, Joseph and Thomas D. Hill. 1989. “Gestr's 'Prime Sign': Source and Signification in Norna-Gests páttr.” Arkiv for nordisk filologi 104: 103-22.

Haukur Porgeirsson. 2018. "How Similar are Heimskringla and Egils saga? An Application of Burrows' Delta to Icelandic Texts.” European Journal of Scandinavian Studies 48:1: 1-18.

Helgi Porláksson. 1994. “Hvað er blóðhefnd?” In Sagnaping helgað Jónasi Kristjánssyni sjötugum. Reykjavík. 389-413.

Hermann Pálsson. 1983. "Eftir Njálsbrennu.” Andvari 118: 47-50.

Jaffe, Eric. 2011. "The Complicated Psychology of Revenge.” Observer 24.8 (October). https://www.psychologicalscience.org/observer/the-complicated-psychology-of-revenge (accessed December 17, 2019).

Jónas Kristjánsson. 1990. “Var Snorri Sturluson upphafsmaður Íslendingasagna?” Andvari, nýr flokkur 32: 85-105.

Kundera, Milan. 1993. Les testaments trahis. Collection Folio, 2703. Paris.

Le Goff, Jacques. 1984. The Birth of Purgatory. Trans. Arthur Goldhammer. London.

Lönnroth, Lars. 1969. "The Noble Heathen: A Theme in the Sagas." Scandinavian Studies 41: 1-29.

Miller, William Ian. 1990. Bloodtaking and Peacemaking: Feud, Law, and Society in Saga Iceland. Chicago.

Orning, Hans Jacob. 2018. "Feud in the State: The Conflict between Haakon Haakonsson and Skule Baardsson.” In Emotion, Violence, Vengeance and Law in the Middle Ages. Ed. Kate Gilbert and Stephen White. Medieval Law and its Practice, 24. Leiden \& Boston. 202-24.

Orri Vésteinsson. 1996. The Christianisation of Iceland: Priests, Power and Social Change 1000-1300. Oxford.

Paola Rebughini. 2014. "Subject, Subjectivity, Subjectivation." Sociopedia.isa (2015): 1-11. http://www.sagepub.net/isa/admin/viewPDF.aspx?\&art=2nd\%20Coll\%20Subject,subjec tivity.pdf (accessed December 17, 2019).

Southern, Richard W. 1970. Western Society and the Church in the Middle Ages. Penguin History of the Church, 2. London.

Sverrir Jakobsson. 2016. Auðnaróðal. Baráttan um Ísland 1096-1281. Reykjavík.

Torfi H. Tulinius. 2000. "The Matter of the North: Fiction and Uncertain Identities in ThirteenthCentury Iceland." In Old Icelandic Literature and Society. Ed. Margaret Clunies Ross. Cambridge Studies in Medieval Literature, 42. Cambridge. 242-65.

Torfi H. Tulinius. 2014. The Enigma of Egill: The Saga, the Viking Poet, and Snorri Sturluson. Islandica, 57. Ithaca, NY.

Torfi H. Tulinius. 2015. “Seeking Death in Njáls saga.” In New Norse Studies. Ed. Jeffrey Turco. Islandica, 58. Ithaca, NY. 99-116.

Torfi H. Tulinius. 2016. "Hvers Manns Gagn: Hrafn Sveinbjarnarson and the Social Role of Icelandic Chieftains Around 1200." Saga-Book of Viking Society for Northern Research 40: 91-104.

Torfi H. Tulinius. 2017. "Honour, Sagas and Trauma: Reflections on Literature and Violence in 13th Century Iceland.” In Literature and Honour. Ed. Aasta Marie Bjorvand Bjørkøy and Thorstein Norheim. Oslo. 81-94. 
Torfi H. Tulinius. 2018. "The Social Conditions for Literary Practice." In Snorri Sturluson and Reykholt: The Author and Magnate, His Life, Works and Environment at Reykholt in Iceland. Ed. Guðrún Sveinbjarnardóttir and Helgi Porláksson. Copenhagen. 389-407.

Verderber, Suzanne. 2013. The Medieval Fold: Power, Repression, and the Emergence of the Individual. London.

Vincent, Catherine. 2000. "Rites et pratiques de la pénitence publique à la fin du Moyen Âge: essai sur la place de la lumière dans la résolution de certains conflits." In Actes des congrès de la Société des historiens médiévistes de l'enseignement supérieur public 31, Le règlement des conflits au Moyen Âge. 351-67. 